\title{
Normal Breastfeeding after Breast Reconstruction in a Patient with Poland's Syndrome
}

\author{
Eveline B. Madeira ${ }^{a}$ Júlio C. Queiroz de França ${ }^{a}$ Benedito de Sousa Almeida Filho ${ }^{a}$ \\ Ana L. Nascimento Araújo ${ }^{b}$ Sabas C. Vieira ${ }^{c}$ \\ a Medical students at the Federal University of Piaui - UFPI, \\ bDepartment of Plastic Surgery, Sao Marcos Hospital, \\ 'Department of Oncology, Medical School, Federal University of Piaui, Teresina, Piaui, Brazil
}

\author{
Keywords \\ Poland's syndrome · Mammoplasty · Prostheses · \\ Implants · Breastfeeding
}

\section{Summary}

Background: Poland's syndrome is a rare congenital non-inherited anomaly that usually manifests itself during adolescence and is characterized by absence or deficient development of one of the breasts. To our knowledge, no case of breastfeeding after reconstruction surgery in patients with Poland's syndrome has been described. Case Report: A 22-year-old female patient with Poland's syndrome underwent breast reconstruction. The procedure performed consisted of rotation of a myocutaneous flap harvested from the ipsilateral latissimus dorsi muscle, which was subsequently attached to the anterior thoracic wall to create a pouch and place a $300-\mathrm{ml}$ round textured cohesive silicone gel-filled breast implant. 5 years later the patient got pregnant, and 1 year after delivery she is still breastfeeding normally with both breasts. Conclusion: Reconstruction surgery with the latissimus dorsi muscle and a prosthesis was shown to be a potential and safe solution to achieve improvement of breast symmetry and to provide confidence and comfort in relation to self-image and, moreover, the ability to breastfeed.

\section{Introduction}

Poland's syndrome is a congenital thoracic anomaly usually characterized by breast and nipple hypoplasia or aplasia, scarce subcutaneous tissue, lack of the costosternal portion of the pectoralis major muscle, absence of the pectoralis minor

\author{
Schlüsselwörter \\ Poland-Syndrom - Mammaplastik · Prothese . \\ Implantate $\cdot$ Stillen
}

\section{Zusammenfassung}

Hintergrund: Das Poland-Syndrom ist ein seltener, nicht erblicher Geburtsfehler, der sich gewöhnlich im Jugendalter bemerkbar macht und sich durch die fehlende oder mangelhafte Entwicklung einer der Brüste auszeichnet. Unseres Wissens ist bisher kein Fall von erfolgreichem Stillen nach Brustrekonstruktion bei einer Patientin mit Poland-Syndrom berichtet worden. Fallbericht: Bei einer 22-jährigen Patientin mit Poland-Syndrom wurde eine Brustrekonstruktion durchgeführt. Die Operation bestand aus der Rotation eines vom ipsilateralen Musculus latissimus dorsi gewonnenen myokutanen Lappens und dessen anschließender Befestigung an der vorderen Brustwand, wodurch eine Tasche für ein rundes, strukturiertes und mit kohäsivem Silikongel gefülltes Brustimplantat $(300 \mathrm{ml})$ erstellt wurde. 5 Jahre später wurde die Patientin schwanger, und 1 Jahr nach der Geburt ihres Kindes ist sie noch immer in der Lage, mit beiden Brüsten normal zu stillen. Schlussfolgerung: Die Brustrekonstruktion mit dem M. latissimus dorsi und einer Prothese stellte sich als eine potentielle und sichere Lösung heraus, mit der eine Verbesserung der Brustsymmetrie, des Selbstvertrauens und des Selbstbildes sowie des Stillvermögens erreicht werden kann.

muscle, deformity or aplasia of the costal cartilages, either of the 2 nd to the 4 th ribs or of the 3 rd to the 5 th ribs, and alopecia of the ipsilateral axillary region. Several variants of this condition have been reported $[1,2]$. There are some surgical reconstructive techniques available for patients with this syndrome. However, to our knowledge, there are no reports in

\section{KARGER \\ Fax +497614520714 \\ Information@Karger.de}

www.karger.com (c) 2011 S. Karger GmbH, Freiburg

1661-3791/11/0066-0479\$38.00/0

Accessible online at:

www.karger.com/brc
Eveline Brandão Madeira

4355, Fidalma M. de Carvalho St., B1.06, Apt. 204

Ininga, 64048-040Teresina, Piaui, Brazil

Tel. +55 86-32371817

evelinemadeira@hotmail.com 
the literature on breastfeeding after breast reconstruction. We report a case of breastfeeding in a patient with Poland's syndrome after breast reconstruction with a myocutaneous flap from the latissimus dorsi muscle and a silicone prosthesis, and we discuss the possibilities of breastfeeding after mammoplasty.

\section{Case Report}

A 22-year-old female patient with a diagnosis of Poland's syndrome sought medical advice at our service. Previously, she had undergone 2 reconstructive interventions with the use of tissue expanders in the subcutaneous space and placement of a definitive prosthesis, but both surgical procedures resulted in extrusion of the prosthesis. On physical examination, the patient had a normally developed right breast and absence of the left breast as well as the ipsilateral pectoralis major and minor muscles (fig. 1). A 6-cm diameter incision scar was observed on the left inframammary fold. In March 2004, after unremarkable preoperative test results, the patient underwent another breast reconstruction. The procedure performed consisted of the rotation of a myocutaneous flap harvested from the ipsilateral latissimus dorsi muscle, which was subsequently attached to the anterior thoracic wall to create a pouch and place a 300-ml round textured cohesive silicone gel-filled breast implant. The patient had a good postoperative recovery, and symmetry improvement (fig. 2). 5 years later, the patient got pregnant. Gestation and delivery were normal, and currently, 1 year after delivery, the patient is still breastfeeding normally with both breasts (figs. 3 and 4). The infant was exclusively breastfed until the age of 6 months.

\section{Discussion}

The surgical options for Poland's syndrome include reconstruction with prosthesis after the use of skin expanders placed in the subcutaneous space; reconstruction with latissimus dorsi muscle and prosthesis; reconstruction with unilateral or bilateral rectus abdominis muscle with or without prosthesis, as well as microsurgical techniques [2]. Which treatment strategy is applied in a given patient depends on the extent of the deformity, age, and gender. Because most patients present with severe breast hypoplasia or aplasia, a muscle or myocutaneous flap is required to cover the prosthesis [3]. For this purpose, the latissimus dorsi muscle is a suitable option because it provides coverage and protection of the prosthesis from tension and allows positioning of the skin island at the junction of the upper quadrants, thus lowering the ipsilateral nipple-areola complex location and improving its height in relation to the contralateral breast when dystopia is present. It also increases the amount of tissue volume in this area which usually has a convex and deepened outline due to the costal margin deformities as observed in the present case.

The latissimus dorsi myocutaneous flap rotation approach has also been advocated to correct the loss of axillary muscle bulk. The muscle transposition has the disadvantage of adding a second thoracic scar and removing one of the most important muscles of the shoulder and upper arm [4].

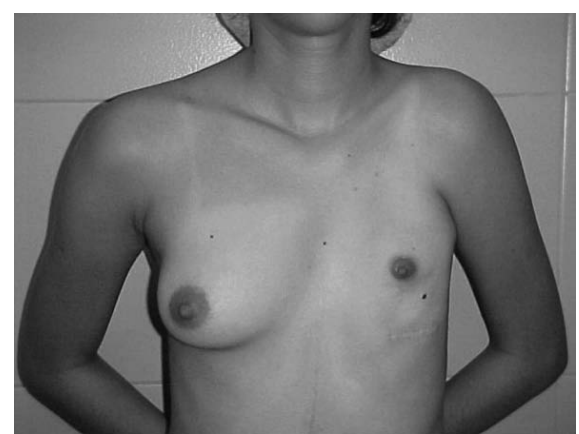

Fig. 1. The patient during the preoperative period with a normally developed right breast and absence of the left breast and the pectoralis major and minor muscles.

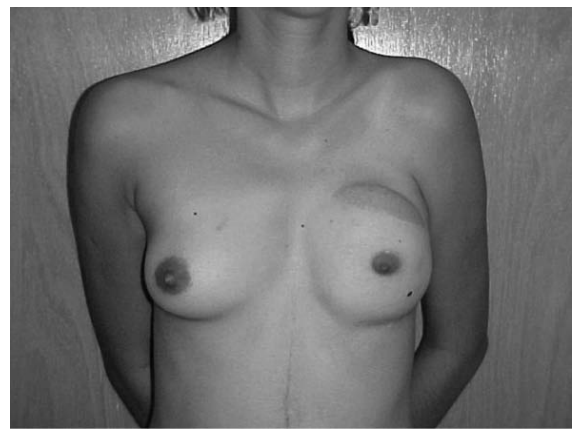

Fig. 2. The patient during the postoperative period with improved breast symmetry.

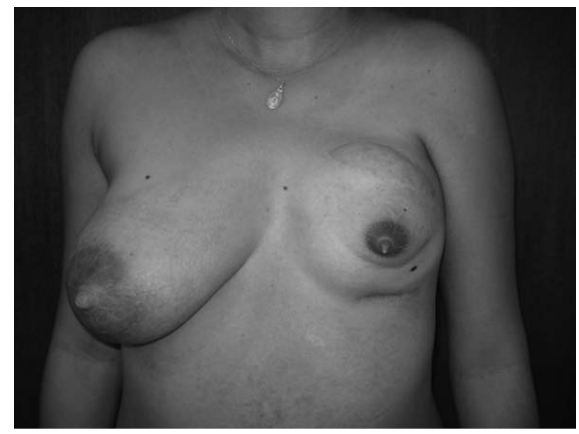

Fig. 3. The patient with lactating breasts after breast reconstruction.

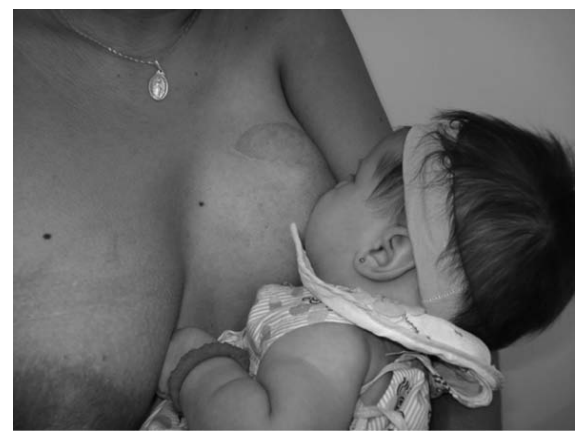

Fig. 4. The patient was able to breastfeed after breast reconstruction.

Potential complications and aesthetic outcome are the primary concerns of the patients who undergo breast reconstruction or mammoplasty. However, in the setting of a future pregnancy, concerns also arise about the inability to breastfeed and subsequent implications for the infant's health [5]. Studies have shown that adolescents who undergo reduction mammoplasty may breastfeed their future children and have a complication rate similar to that observed in the overall population [6, 7]. Nevertheless, the likelihood of breastfeeding after reduction mammoplasty is inversely and proportionally correlated with the amount of resected tissue. In addition, the 
nipple-areola complex transposition techniques have functional advantages when compared to nipple resection with flap reconstruction as they preserve the vascular and nerve supply and with that tactile sensitivity and duct contractibility [8].

Women who undergo augmentation mammoplasty have a significantly higher incidence of insufficient lactation compared to those that do not [9], with the breastfeeding success rate decreasing by $25 \%$ and the need for complementary feeding increasing by $19 \%$ [10]. Periareolar and transareolar approaches have a greater association with insufficient lactation because of the higher potential for duct injury, decreased nerve supply, and reduced nipple-areola sensitivity [7]. The axillary approach carries the risk of intercostal nerve injury, leading to impaired breast sensitivity. In addition, the presence of adhesions and fibrosis at the nipple-areola complex can make it difficult for the infant to suckle, hence decreasing stimulation and subsequently milk production [8].

In the present case, the deficient amount and thickness of the patient's skin resulted in skin necrosis and extrusion of the prosthesis in both attempts of tissue expander reconstruction. Reconstruction techniques for Poland's syndrome should be judiciously selected in order to avoid complications such as those observed in this case. During pregnancy, the reconstructed breast increased in size and had normal lactation compared to the contralateral breast.

\section{Conclusion}

Reconstruction surgery with latissimus dorsi muscle and prosthesis was shown to be a potential and safe solution to achieve improvements in breast symmetry and to provide confidence and comfort in relation to self-image and, moreover, the ability to breastfeed.

\section{Disclosure Statement}

The authors declare no conflict of interest.

\section{References}

${ }_{1}$ Freitas RS, Tolazzi ARD, Martins VDM, et al.: Poland's syndrome: different clinical presentations and surgical reconstructions in 18 cases. Aesthetic Plast Surg 2007;31:140-6.

2 Urshel HC: Poland's syndrome. Chest Surg Clin North Am 2000;10:393-403.

3 Mitsuoka A, Ezaki H, Sumitomo S, et al.: Two cases of severe Poland's syndrome and their repair by sterna turnover and prosthesis; in Wada $\mathrm{J}$, Yokoyama M (eds): Chest Wall Deformities and Their Operative Treatment. Tokyo, AD Printing Inc., 1990, pp. 181-96.
4 Shamberger RC, Welch KJ, Upton J 3rd: Surgical treatment of thoracic deformity in Poland's syndrome. J Pediatr Surg 1989;24:760-5.

5 Turck D: Breast feeding: health benefits for child and mother. Arch Pediatr 2005;12(suppl 3):S143-4.

6 Aillet S, Watier E, Chevrier S, et al.: Breast feeding after reduction mammoplasty performed during adolescence. Eur J Obstet Gynecol Reprod Biol 2002;101:79-82.

7 Thibaudeau S, Sinno H, Williams B: The effects of breast reduction on successful breastfeeding: a systematic review. J Plast Reconstr Aesthet Surg 2010;63:1688-93.
8 Dornaus MFP: A experiência de amamentação de um grupo de mulheres com mamoplastia redutora e de aumento (tese). São Paulo (SP): Escola de Enfermagem da Universidade de São Paulo/USP, 2005.

9 Hurst NM: Lactation after augmentation mammoplasty. Obstet Gynecol 1996;87:30-4.

10 Cruz NI, Korchin L: Breastfeeding after augmentation mammoplasty with saline implants. Ann Plast Surg 2010;64:530-3. 